Historic, Archive Document

Do not assume content reflects current scientific knowledge, policies, or practices. 



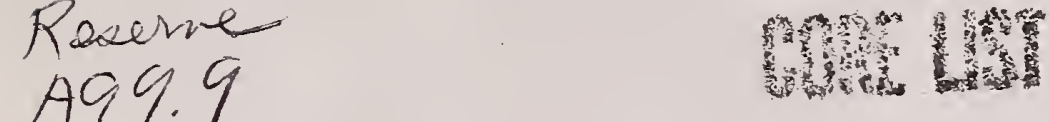

$F 76324$

Selection and Use of Snags by Secondary Cavity-Nesting Birds of the Ponderosa Pine Forest
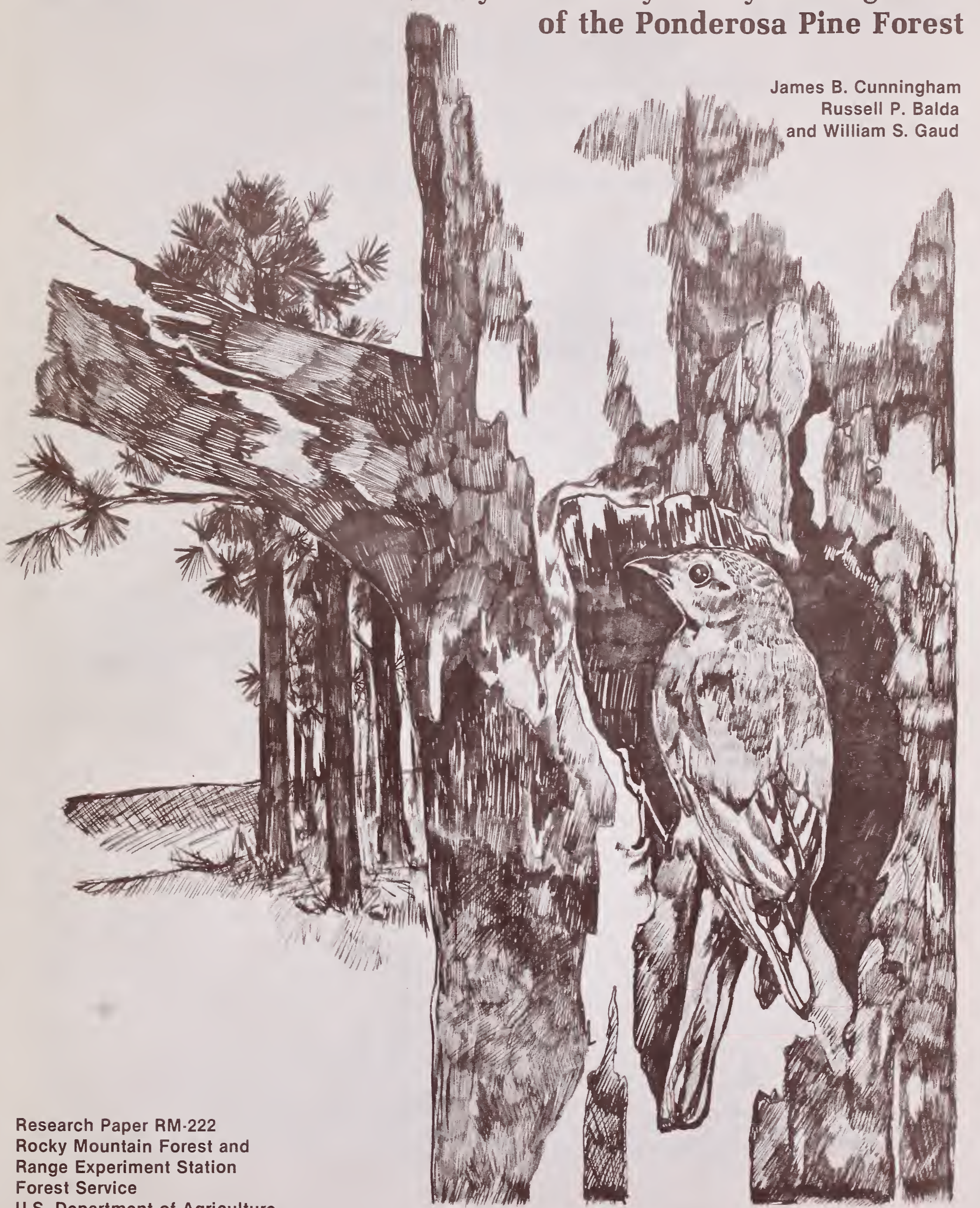


\title{
2"Selection and Use of Snags by Secondary Cavity-Nesting Birds of the Ponderosa Pine Forest ${ }^{1}$
}

\author{
James B.|Cunningham, Russell P. Balda, and William S. Gaud²
}

\begin{abstract}
520
Abstract

One factor limiting the population size of secondary cavity-nesting birds in ponderosa pine is the number of suitable nesting cavities. Snags in the pine forest provide a large number of species with nesting and roosting sites. To maintain secondary cavity nesters at their natural population level, a density of 5.2 snags per ha is recommended for mature ponderosa pine. $\because$
\end{abstract}




\title{
Selection and Use of Snags \\ by Secondary Cavity-Nesting Birds of the Ponderosa Pine Forest
}

\author{
James B. Cunningham, Russell P. Balda, and William S. Gaud
}

\section{Management Highlights}

The results of this investigation indicate that snags are important as nest and roost sites; provide a large number of bird species with hawking, singing and drumming, or perching posts; and provide a feeding substrate for many species. The following guide to the characteristics of desirable snags is proposed:

1. Diameter of snags should be greater than $33 \mathrm{~cm}$.

2. Total height of snags should be greater than $6 \mathrm{~m}$.

3. Percent bark cover should be greater than $40 \%$.

4. Snags which have broken tops should be saved if they also fit the above criteria.

5. Ponderosa pine snags in the most frequently used age range of 5-29 years should be saved.

6 . In areas where the available snags are below the size range stated above, the largest snags should be saved.

7. Snags with existing cavities should be given preference.
8. In areas where oaks are found and oak removal is to occur, those oaks with a diameter of $27 \mathrm{~cm}$ and greater should be saved as suitable nest sites.

9. Secondary cavity nesters such as the whitebreasted nuthatch utilize the dead strips from lightning strikes. Since such trees are usually poor quality timber trees, they should be saved for immediate use by the birds and as a means of producing future snags.

10. Hard snags could be removed in preference to soft snags, if necessary, but, if possible, hard snags should be saved as territory and perching posts.

11. Those live ponderosa pines with dead tops should be left for nest and roost sites and for future snag replacement.

12. Balda (1975) suggested that the density of snags should be 6.5 snags per ha to maintain secondary cavity nesters at natural levels. Evidence from this study indicates that 5.2 snags per ha is a more realistic density in a mature ponderosa pine forest.

\section{Introduction}

Cavity-nesting birds are a widespread and common group of species from many families and orders. (Scientific names of flora and fauna referred to in this paper are listed in the appendix.) Cavity-nesting birds sometimes roost in natural or excavated holes, crevices, or cavities in trees. Secondary cavity nesters (SCN's)principally ascines (chickadees, tits, nuthatches, and some creepers), wrens, flycatchers, bluebirds, swallows, starlings, and warblers-lack the morphological adaptations necessary for excavating their own cavities. Most of them use natural cavities or cavities excavated by woodpeckers. Thus, the number of suitable nesting cavities is the primary limiting factor on SCN population size (Allen and Nice 1952; Balda 1970, 1975; Burns 1960; Elliot 1945; von Haartman 1957; Power 1966; Zeleny 1972).

MacKenzie (1952) observed that SCN populations increased when unlimited nesting and roosting sites (nesting boxes) were supplied. As long as there were suf- ficient nesting and roosting sites, other density-limiting factors, such as food. did not affect the population.

In the forests of Finland where silvicultural practices have been implemented, bird species diversity was always lower on treated compared to nontreated forests (Haapanen 1965). This difference was due primarily to the drastic reduction in the cavity-nesting species in the treated areas. The climax stage of the forest was the most favorable for cavity nesters because of the abundance of old and dying trees (Haapanen 1965). In 1971, von Haartman found that a reduction in nest box density had a drastic effect upon the density of the pied flycatcher, indicating that nesting sites were an important limiting factor for this cavity nester. If, on treated forests, no trees are allowed to grow beyond some predetermined maximum age, then no trees will reach a stage of rot or decay suitable to the formation of snags used by cavitynesting birds.

Balda (1975) found violet-green swallows and mountain chickadees to be absent from areas where snags 
were also absent, indicating that the densities of these two species were directly related to snag density. An important source of nesting and roosting sites, hawking and foraging sites, and drumming posts for SCN's is snags, standing dead trees, or live trees with dead tops. Snags are produced by forest fires, insects, disease, lightning, and other factors. The number of snags available is, however, limited both by management practices and by natural factors.

Szaro and Balda (1979) found that insectivorous birds in the southwestern ponderosa pine forest spend about $10 \%$ of their time foraging on snags. Since snags comprise far less than $10 \%$ of the biomass of the forest, this indicates snags are a preferred foraging substrate. Swallows and bluebirds use snags extensively for hawking sites. Woodpeckers use snags as sites for drumming; whereas, other species use snags as singing perches when attracting mates and defending territories.

Snags are a fire hazard because of the tendency of burning snags to scatter hot material and thus spread fires (Keen 1929, 1955). They also pose a safety hazard to equipment operators in logging operations. For these reasons, snags commonly have been removed from a forest during timber harvest or fire-control operations. These snag removal practices, plus the heavy increase in the use of snags as fuelwood, have led to a drastic reduction in the number of snags on both public and private forest lands.

The short time snags naturally remain standing further limits the number of snags available to SCN's. In addition, snags are not utilized efficiently by SCN populations, making an abundant supply desirable. Not every snag or every cavity is suitable as a nesting site, nor will every type of SCN utilize every type of snag or cavity. Even during the breeding season, a high percentage of holes may be unoccupied (Dennis 1971), possibly because of strong cavity specificity of the different species.

Snags should be widely distributed because their location limits the habitat of individual birds to the immediate vicinity of the snag. Concentration of snags in limited areas and elimination of many snags has led to what appears to be severe intraspecific and interspecific competition for nesting sites. Such competition is normally rare among SCN's because encounters occur only in the immediate vicinity of the cavity entrance.

Pied flycatchers were found to defend the area around the cavity entrance from conspecifics and from other species such as the great tit (von Haartman 1957). In most cavity-nesting species, the male selects a suitable cavity and then attracts a female. Since the male must be near enough to the cavity to drive off potential competitors for the cavity and also to demonstrate the suitability of the cavity to the female, he can only defend a restricted area.

The importance of cavities to the survival of winterroosting birds has been studied by Moore (1945) and Kendeigh (1960). Because of cold temperatures, long periods of darkness, and the associated lack of energy intake during this time, nighttime is the critical period for wintering birds. It is advantageous for overwintering birds to select winter roosts that are well insulated and retain heat.

Kendeigh (1960) noted that in order for birds to winter in regions beyond their winter thermal range, they must be able to roost in cavities. This would be particularly important for small birds, such as the pygmy nuthatch, in which the surface to volume ratio is high. These birds utilize cavities as roost sites during the winter and appear to select for those qualities which reduce heat loss.

Keen (1955) found that snags between the ages of 5 and 15 years fell very rapidly. This is consistent with our finding. He also found that, after 25 years, only $10 \%$ of the snags were still standing. In contrast, after 25 years, $40 \%$ were standing; and after 50 years, $25 \%$ of the snags were still standing in the ponderosa pine forest.

This study was designed to establish the relationship between the quality and quantity of snags present in the ponderosa pine forest of northern Arizona and the density and diversity of SCN's. Criteria for identifying and preserving desirable snag trees are developed from the findings.

\section{Study Areas}

All areas used for this study (lats. $34^{\circ} 20^{\prime}-35^{\circ} 16^{\prime} \mathrm{N}$., longs. $110^{\circ} 45^{\prime}-111^{\circ} 48^{\prime} \mathrm{W}$., 1,981 - to $2,256-\mathrm{m}$ elevation) are within the Coconino National Forest, Coconino County, Arizona, in the ponderosa pine vegetation type. Areas studied were the G. A. Pearson Natural Area in the Fort Valley Experimental Forest; watersheds 8, 13, 14 , and 17 , and the Monument Tanks study area in the Beaver Creek Watershed; and Rocky Park and Gash Flat in the Woods Canyon Watershed. At the time of this study, watersheds 8,14 , and 17 had recently been subjected to thinning treatments.

\section{G. A. Pearson Natural Area}

The G. A. Pearson Natural Area is $14.5 \mathrm{~km}$ northwest of Flagstaff along U.S. Highway 180 (fig. 1). The 10-ha study area is on a south-facing slope within plot 61 of the Fort Valley Experimental Forest. This area has remained relatively untouched for the last 60 years, although a few snags have been removed by woodcutters. During the study, the ponderosa pine density of more than $7.6 \mathrm{~cm}$ was 489 trees per ha, with a foliage volume of $49,658 \mathrm{~m}^{3}$ per ha. There were 5.2 snags per ha. There was no Gambel oak on this study plot.

\section{Watershed 8}

Watershed 8 is $64 \mathrm{~km}$ southeast of Flagstaff on Forest Road 213 near Stoneman Lake (fig. 2). The 15-ha study area, on a west-facing slope of about $13^{\circ}$, is in 


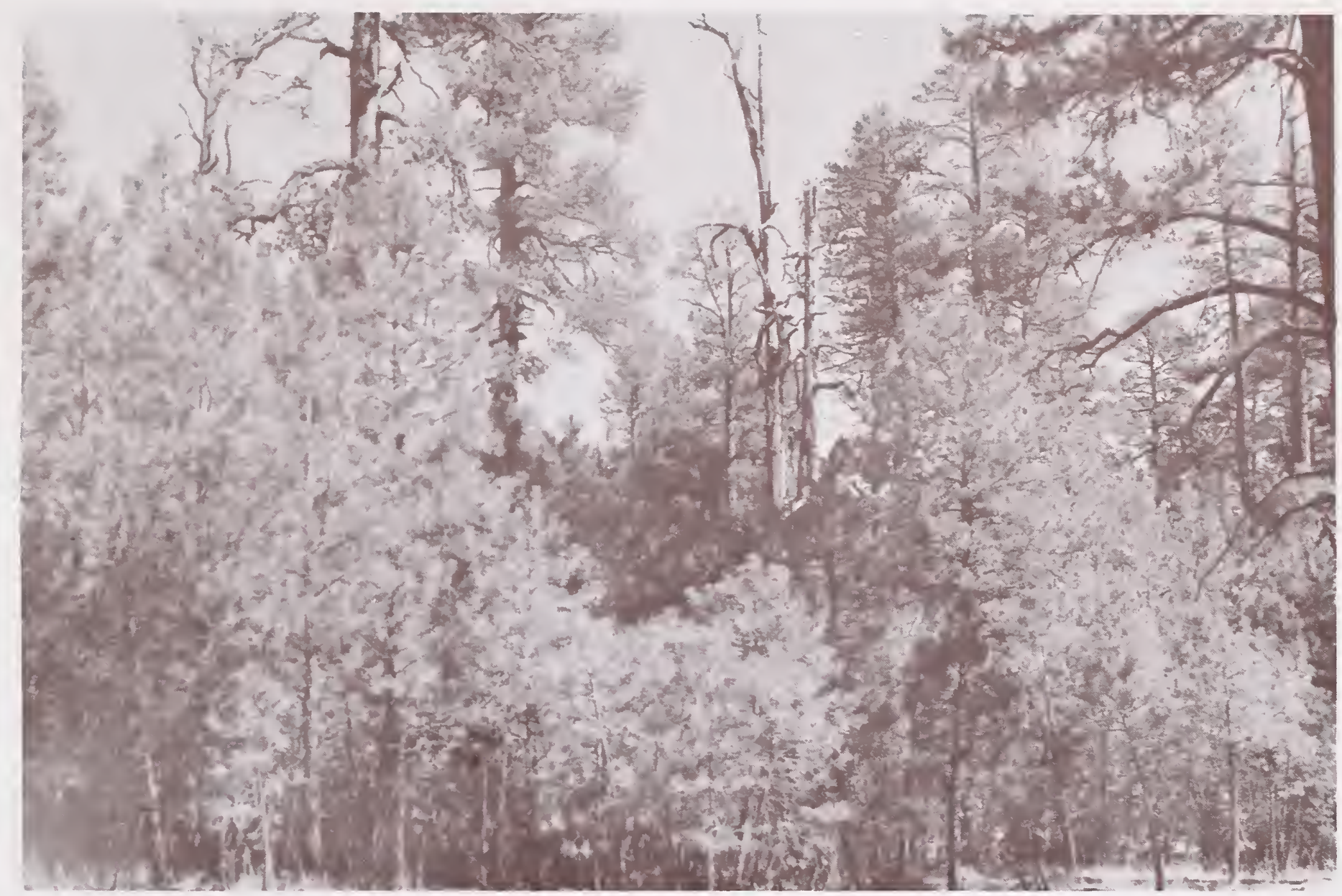

Figure 1.-G. A. Pearson Natural Area. Note the dense thickets and snags.

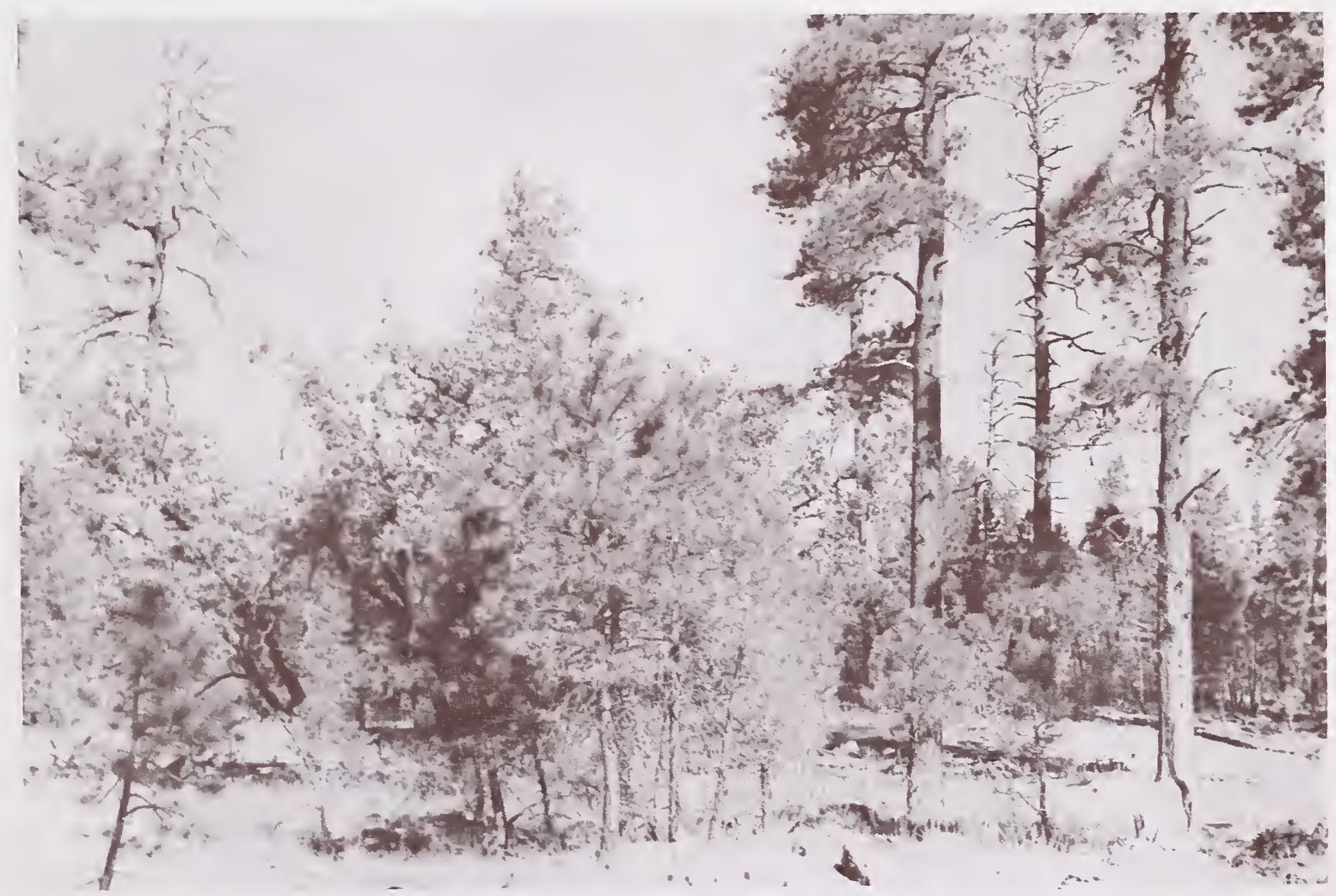

Figure 2. - Watershed 8 study area. Note the snags and the openness due to treatment. 
the southwest corner of the 729-ha watershed. Larson ${ }^{3}$ and Szaro and Balda (1979) state that, after treatment, the ponderosa pine and Gambel oak densities were 216 and 20 trees per ha, respectively. The total foliage volume was $17,039 \mathrm{~m}^{3}$ per ha. Ponderosa pine foliage volume was $14,169 \mathrm{~m}^{3}$ per ha. During the 1975 breeding season, there were 1.5 snags per ha. In the late summer and fall of 1975, slash was piled and the number of snags reduced to 1.4 per ha.

\section{Watershed 14}

Watershed 14 is $68 \mathrm{~km}$ southeast of Flagstaff on Forest Road 230 (fig. 3). The study area is on a southfacing slope of about $9^{\circ}$. The 15-ha plot is in the southeast corner of the 221-ha watershed. Brown ${ }^{4}$ and Szaro and Balda (1979) state that the ponderosa pine, Gambel oak, and alligator juniper densities after treatment were 145,34 , and 0.8 trees per ha, respectively. The total foliage volume was $6,526 \mathrm{~m}^{3}$ per ha; whereas, ponderosa pine foliage volume was $4,382 \mathrm{~m}^{3}$ per ha. The ponderosa pine snag density was 0.2 per ha.

\section{Watershed 17}

Watershed 17 is $43 \mathrm{~km}$ south of Flagstaff off Interstate Highway 17 on Forest Road 226. The 15-ha plot is

${ }^{3}$ Larson, Frederick R. 1972. Watershed 8 treatment plan. Rocky Mountain Forest and Range Experiment Station. Flagstaff, Ariz. Unpublished.

'Brown, Harry E. 1969. Watershed 14 treatment plan. Rocky Mountain Forest and Range Experiment Station. Flagstaff, Ariz. Unpublished. on a southwest-facing slope of about $8^{\circ}$. The study area is in the southwest corner of the 49-ha watershed. Brown ${ }^{5}$ and Szaro and Balda (1979) state that after the 1969 prescribed treatment, the ponderosa pine density was 59 trees per ha, and the Gambel oak density was 9 trees per ha. The total canopy volume and ponderosa pine foliage volume were 3,990 and $3,390 \mathrm{~m}^{3}$ per ha, respectively. All snags had been removed during treatment.

\section{Watershed 13}

Watershed 13 is $66 \mathrm{~km}$ southeast of Flagstaff on Forest Road 230. The study area is on a southwestfacing slope of about $17^{\circ}$. The area was not treated before this study. Ponderosa pine density was 583 trees per ha. Gambel oak density was 54 trees per ha. The total foliage volume was $19,370 \mathrm{~m}^{3}$ per ha, $16,437 \mathrm{~m}^{3}$ of which was ponderosa pine. During the 3 years of this study, the density of snags remained at 3.2 per ha.

\section{Monument Tanks}

The Monument Tanks study area is $70 \mathrm{~km}$ southeast of Flagstaff on Forest Road 230 (fig. 4). The 15-ha plot faces west with a slope of approximately $12^{\circ}$. The area had not been treated since the mid-1940's. The ponderosa pine, Gambel oak, and alligator juniper densities were 350,31 , and 52 trees per ha, respectively.

${ }^{5}$ Brown, Harry E. 1968. Watershed 17 treatment plan. Rocky Mountain Forest and Range Experiment Station. Flagstaff, Ariz. Unpublished.

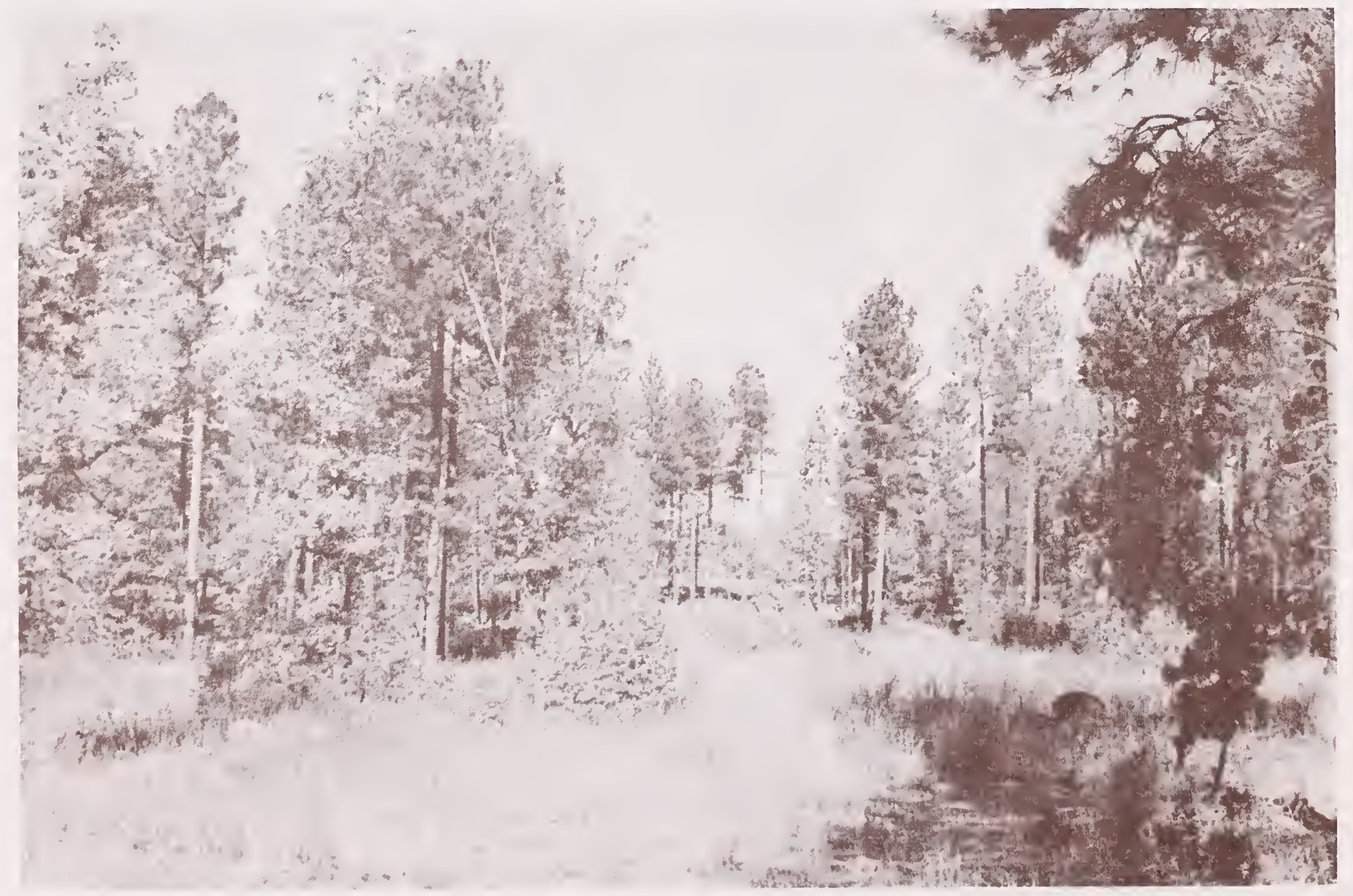

Figure 3.-Watershed 14 study area. Note the open strip area and the lack of snags. 


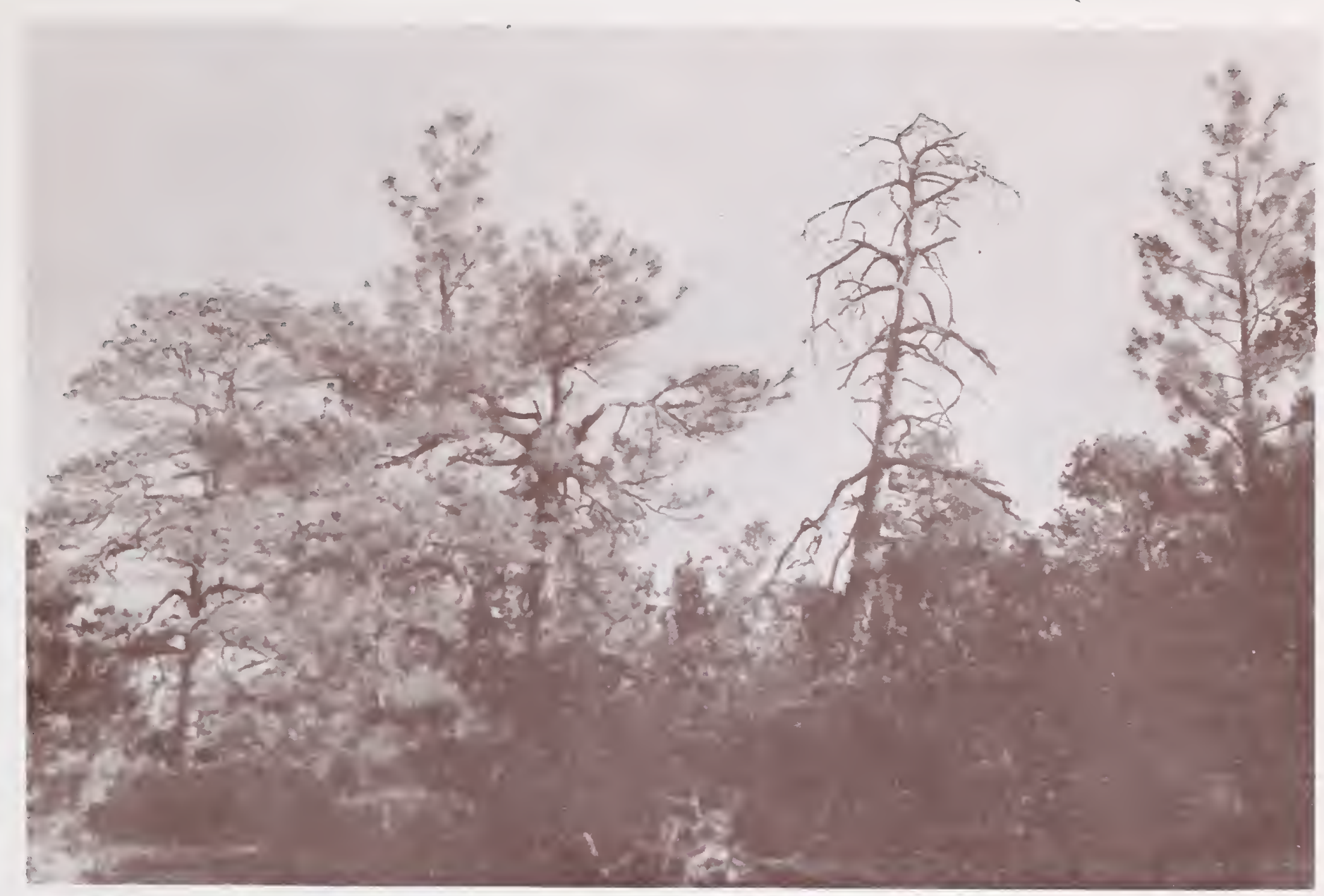

Figure 4.-Monument Tank study area. Note the short stunted growth and the snags.

The total foliage volume was $31,710 \mathrm{~m}^{3}$ per ha; whereas, the ponderosa pine foliage volume was $15,697 \mathrm{~m}^{3}$ per ha. The snag density was 3.7 per ha.

\section{Rocky Park}

The Rocky Park study area is $43 \mathrm{~km}$ south of Flagstaff on Forest Road 80 (fig. 5). The 12.5-ha plot is essentially flat. No prescribed treatment had been conducted on this area since the mid-1940's. The density of ponderosa pine was 460 trees per ha with a canopy volume of $56,163 \mathrm{~m}^{3}$ per ha. Gambel oak density was 15 trees per ha. The total foliage volume was $58,003 \mathrm{~m}^{3}$ per ha. During the 1977 breeding season, the snag density was 1.1 snags per ha; in 1978 , the snag density was reduced to 1.0 per ha.

\section{Gash Flat}

The Gash Flat study area is $60 \mathrm{~km}$ southeast of Flagstaff on Forest Road 127 (fig. 6). The area is essentially flat. At the time of the study, no treatment of the area had occurred since 1947. The ponderosa pine and Gambel oak densities were 178 and 20 trees per ha, respectively. The total foliage volume was $50,187 \mathrm{~m}^{3}$ per ha; whereas, the ponderosa pine foliage volume was $46,499 \mathrm{~m}^{3}$ per ha. Snag density was 3.5 per ha during both breeding seasons.

\section{Methods and Materials}

\section{Snags and Vegetation}

In each of the study plots, the position of all snags greater than $6.1 \mathrm{~m}$ in height and greater than $30.5 \mathrm{~cm}$ in d.b.h. was mapped and numbered. The basal area and height were determined with a d.b.h. conversion tape and abney level, respectively.

The presence or absence of bark, the degree of decay of the wood, the presence or absence of small branches, and the presence or absence of large branches were recorded for each snag located on the G. A. Pearson Natural Area, and watersheds 8 and 14. Height of each cavity and the number of cavities per snag were also recorded on these areas.

During the winter and early spring of 1976, all snags on the G. A. Pearson Natural Area were surveyed. Since 1920 , the vigor, condition, and time of death of all trees larger than $9.1 \mathrm{~cm}$ d.b.h. within this area have been recorded by the USDA Forest Service. Thus, the time of death for each tree, within a 5- to 10 -year period, could be accurately established. A list was compiled of all the trees which died and the years in which they died. A field check was made to determine whether these snags were felled by natural causes or by cutting. Stumps or entire logs with roots exposed or entire logs apparently broken off were counted as snags fallen by natural 


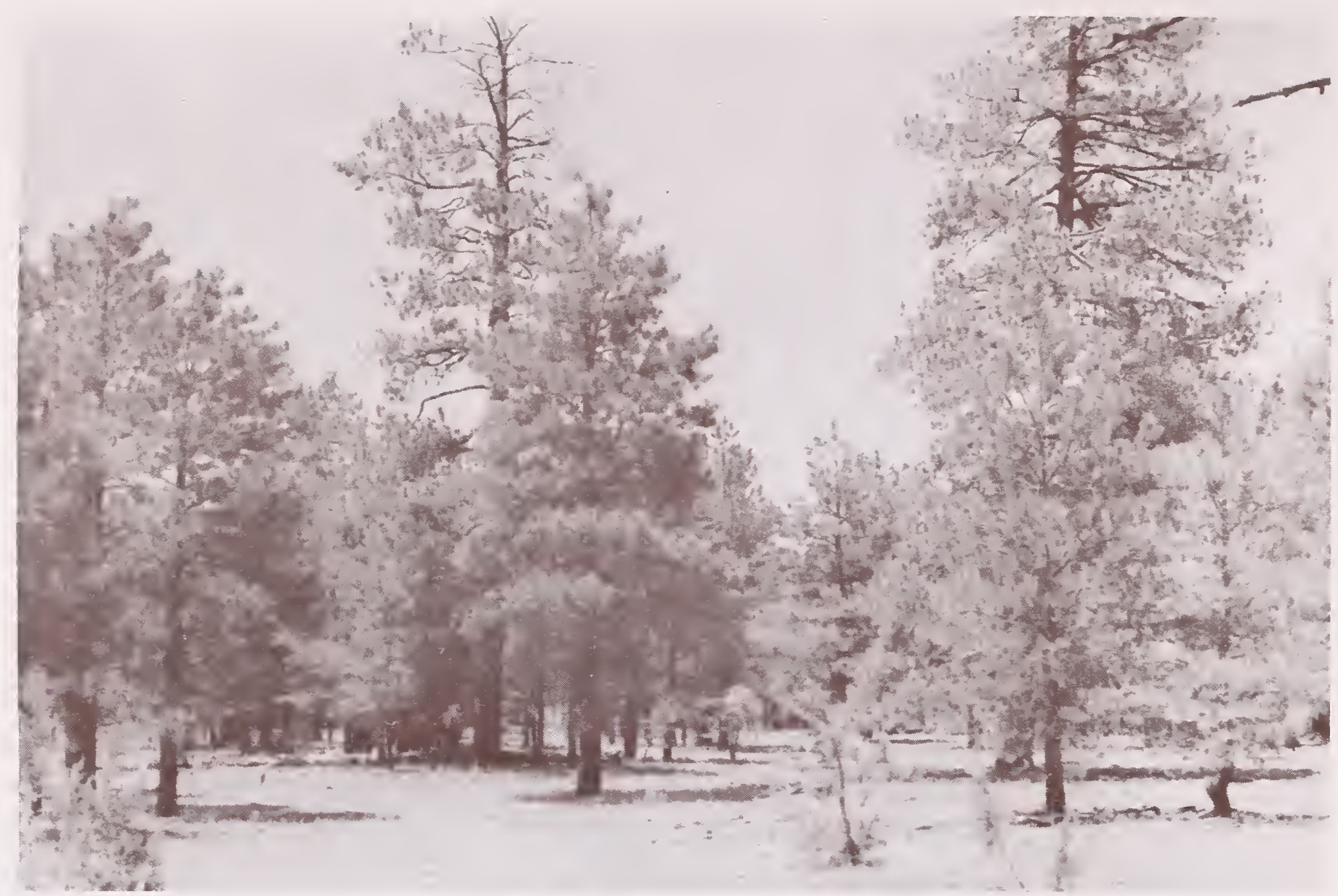

Figure 5.-Rocky Park study area. Note the open areas and the thickets.

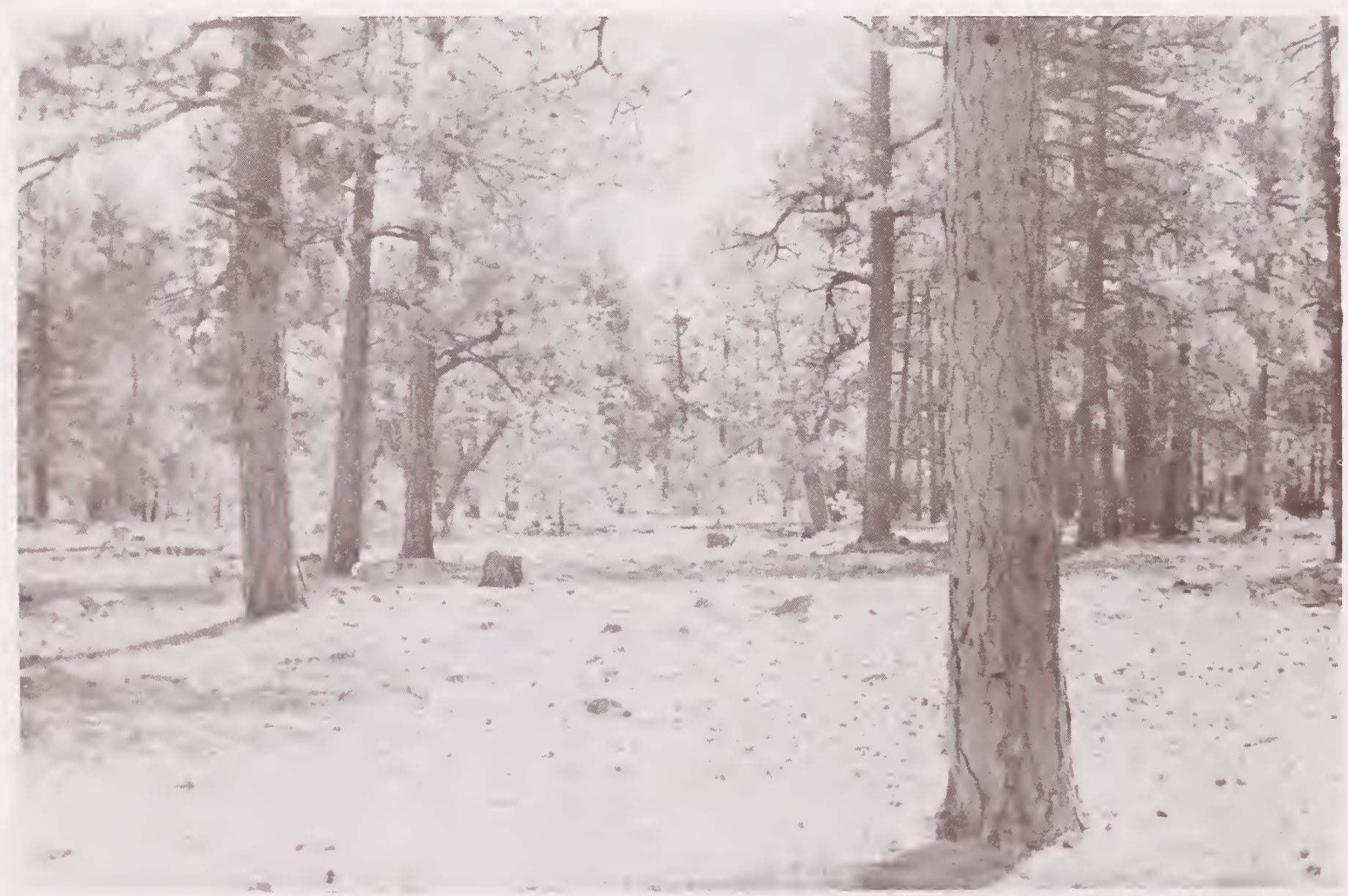

Figure 6.-Gash Flat study area. Note the large trees and the open areas around the trees. 
causes. In cases where a snag obviously had been cut, it was removed from the list. In addition, snags less than $25.4 \mathrm{~cm}$ d.b.h. were deleted because, in most cases, it was impossible to determine whether these trees had been cut or had fallen naturally.

Vegetation data used to determine absolute densities and foliage volumes were collected on all the study areas and analyzed using the procedures described by Szaro and Balda (1979).

\section{Birds}

Complete breeding bird censuses were made using the spot-map method (Kendeigh 1944). During the 1975 and 1976 breeding seasons, locations of individual birds and their nest sites were recorded for secondary cavity-nesting species on the G. A. Pearson Natural Area and watersheds 8 and 14. In addition, nest sites were recorded outside these three study plots in areas homogenous with the study plot. When a nest site was found, the following information was recorded:

1. D.b.h. of the tree containing the nest.

2. Height of cavity from ground.

3. Presence or absence of bark around cavity.

4. Estimate of the percent of bark on snag.

5. Presence or absence of a top on snag.

6 . Total height of snag.

During the winter of 1975-1976, roost cavities were located for pygmy nuthatches in the G. A. Pearson Natural Area. The same series of data was collected for roost sites as was gathered for nest sites.

Species differences in mean d.b.h., mean height of cavity, and mean height of snag were tested using analysis of variance. The chi-square statistic $(P=0.05)$ was used to test species differences in the percentage of bark of snags used, the percentage of nests in snags, the percentage of nests with bark around the cavity entrance, and the percentage of nests in snags with a top present.

The effect of foliage volume and snag density on the density of breeding SCN's was examined using stepwise, multiple-linear regression. Factors used in this test were SCN density, snag density, total foliage volume, ponderosa pine foliage volume, and foliage volume contributed by other trees. Regression analysis was also used to determine the relationship between time and percentage of snags standing. Data on breeding densities of SCN's were gathered from eight study areas over a number of years by different workers. All studies used the same techniques to determine foliage volume, snag density, and breeding bird density.

The authors studied the G. A. Pearson Natural area and watersheds 8 and 14 in 1975 and 1976; and Gash Flat, Rocky Park, and Monument Tanks in 1977 and 1978. Szaro and Balda (1979) studied watershed 8 in 1974; watershed 14 in 1973 and 1974; and watersheds 13 and 17 in 1973, 1974, and 1975.
Results

\section{Bird Populations}

The number of species of SCN's fluctuated between three and eight and showed no overall trend with an increase in snag density. On all study plots, the average number of SCN species was six. This constitutes approximately $30 \%$ of the total bird species breeding on these areas. The relative proportion of the total population contributed by the SCN's showed a correlation (table 1) of $\mathrm{r}=0.78$ with snag density (fig. 7). This suggests that with more snags present, the SCN's make up proportionally more of the total population.

The highest absolute densities of SCN's occurred on the G. A. Pearson Natural Area, and the lowest on watershed 17 (table 2). A test of bird density against foliage volume and snag density resulted in a significant regression. The three independent variables chosen were snag density $(r=0.74)$, foliage volume of trees other than ponderosa pine $(r=-0.15)$, and ponderosa pine foliage volume $(r=0.72)$. For the eight areas, $76 \%$ of the variability in bird densities was explained by these three independent variables $(\mathrm{P}<0.001)$ (table 3).

\section{Percentage of Nests in Snags}

The percentage of nests placed in snags varied among the SCN's (table 4). The violet-green swallow showed a strong preference for snags, nesting exclusively in them. Both the pygmy nuthatch and the western bluebird also used snags as nest sites in high proportions, but shifted from snags to live pines or oaks in low snag density areas. The brown creeper utilized snags only for nest sites; whereas, the white-breasted nuthatch most often nested in live trees, especially in live oaks.

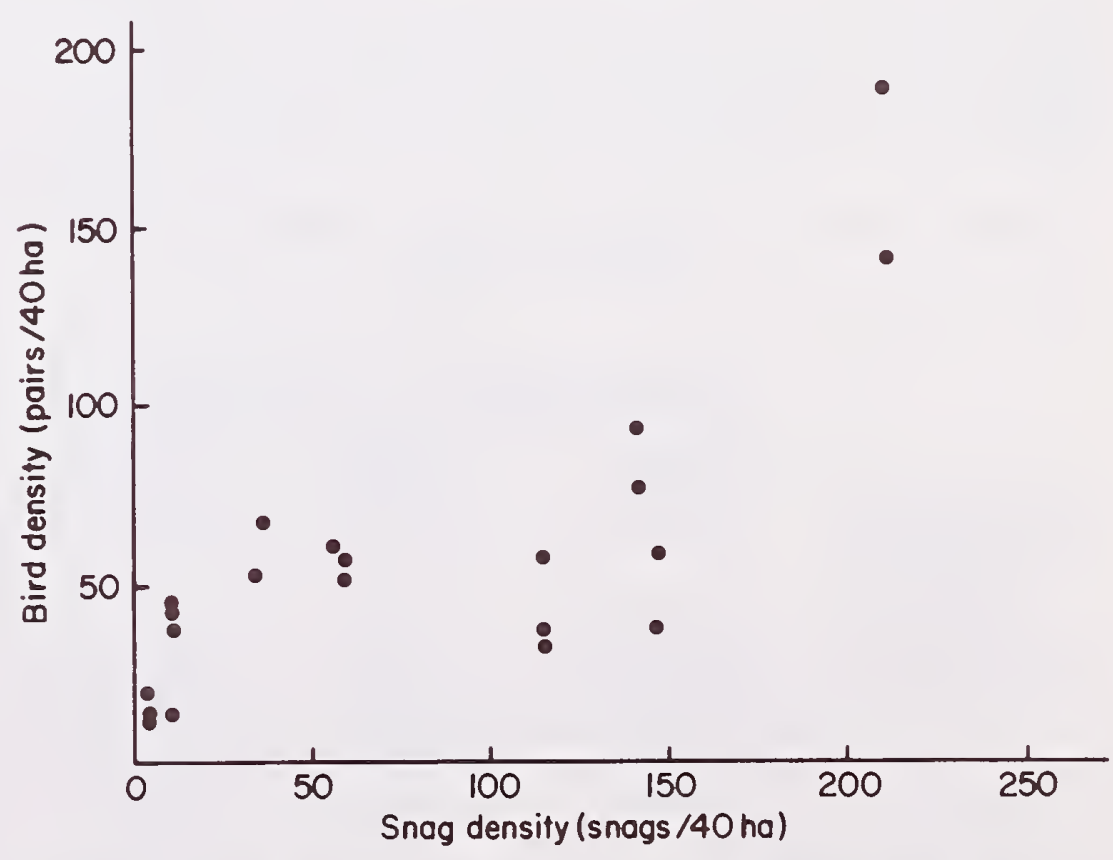

Figure 7.-The relationship between snag density and density of SCN's. 
Table 1.-Breeding densities of SCN's per 40 ha

\begin{tabular}{lcccr}
\hline Study area & Years & $\begin{array}{c}\text { Average number } \\
\text { of snags }\end{array}$ & $\begin{array}{c}\text { Average number } \\
\text { (and percent) of } \\
\text { species of SCN's }\end{array}$ & $\begin{array}{c}\text { Total number } \\
\text { (and percent) of } \\
\text { pairs of SCN's }\end{array}$ \\
\hline G. A. Pearson & & & & \\
$\quad$ Natural Area & $75-76$ & 208 & $6(32)$ & $167(55)$ \\
Monument Tanks & $77-78$ & 147 & $6(30)$ & $45(45)$ \\
Gash Flat & $77-78$ & 141 & $6(26)$ & $85(40)$ \\
Watershed 13 & $73-75$ & 127 & $6(37)$ & $42(45)$ \\
Watershed 8 & $74-76$ & 58 & $7(31)$ & $56(36)$ \\
Rocky Park & $77-78$ & 44 & $6(31)$ & $31(37)$ \\
Watershed 14 & $73-76$ & 11 & $5(24)$ & $15(27)$ \\
Watershed 17 & $73-75$ & 0 & $3(21)$ & $15(20)$ \\
\hline
\end{tabular}

Table 2.-Average number of nesting pairs of SCN's (pairs per 40 ha)

\begin{tabular}{|c|c|c|c|c|c|c|c|c|}
\hline Species & $\begin{array}{l}\text { G. A. Pearson } \\
\text { Natural Area }\end{array}$ & $\begin{array}{c}\text { Gash } \\
\text { Flat }\end{array}$ & $\begin{array}{c}\text { Rocky } \\
\text { Park }\end{array}$ & $\begin{array}{l}\text { Monument } \\
\text { Tanks }\end{array}$ & $\begin{array}{c}\text { Watershed } \\
8\end{array}$ & $\begin{array}{c}\text { Watershed } \\
13\end{array}$ & $\begin{array}{c}\text { Watershed } \\
14\end{array}$ & $\begin{array}{c}\text { Watershed } \\
17 \\
\end{array}$ \\
\hline \multicolumn{9}{|l|}{ Violet-green } \\
\hline swallow & 45 & 19 & 18 & 6 & 10 & 9 & 2 & 0 \\
\hline Pygmy nuthatch & 42 & 33 & 21 & 18 & 16 & 14 & 6 & 1 \\
\hline Western bluebird & 26 & 16 & 9 & 6 & 12 & 5 & 12 & 6 \\
\hline Mountain chickadee & 26 & 6 & 4 & 7 & 4 & 4 & 3 & 1 \\
\hline \multicolumn{9}{|l|}{ White-breasted } \\
\hline nuthatch & 12 & 7 & 6 & 6 & 9 & 6 & 9 & 7 \\
\hline Brown creeper & 14 & 1 & 3 & 1 & 0 & 0 & 0 & 0 \\
\hline House wren & 0 & 0 & 0 & 0 & 0 & 0 & 2 & 0 \\
\hline Western flycatcher & 2 & 2 & 0 & 0 & 4 & 5 & 0 & 0 \\
\hline Flammulated owl & 0 & 0 & 0 & 0 & 2 & 0 & 0 & 0 \\
\hline American kestrel & 0 & 0 & 0 & 0 & 0 & 0 & 1 & 0 \\
\hline Total & 167 & 84 & 61 & 44 & 57 & 43 & 35 & 15 \\
\hline
\end{tabular}

Table 3.- Values for variables used in developing a regression model for SCN's

\begin{tabular}{|c|c|c|c|c|}
\hline & Standard error & $\mathbf{R}^{2}$ & $\mathrm{R}^{2}$ change & $\mathbf{F}$ \\
\hline \multirow{3}{*}{$\begin{array}{l}\text { Snag density } \\
\text { Nonponderosa } \\
\text { pine foliage } \\
\text { volume } \\
\text { Ponderosa pine } \\
\text { foliage volume }\end{array}$} & $9.98 \times 10^{-2}$ & 0.54 & 0.54 & 16.66 \\
\hline & $1.32 \times 10^{-3}$ & .71 & .17 & 6.08 \\
\hline & $3.39 \times 10^{-4}$ & .76 & .05 & 3.72 \\
\hline \multirow{3}{*}{\multicolumn{5}{|c|}{$\begin{array}{l}D F_{\text {regression }}=3 \\
D F_{\text {residual }}=17 \\
\text { Regression equation: }\end{array}$}} \\
\hline & & & & \\
\hline & & & & \\
\hline \multicolumn{5}{|c|}{$y=20.8+0.407 x_{1}-3.27 \times 10^{-3} x_{2}+6.54 \times 10^{-4} x_{3}$} \\
\hline
\end{tabular}

Table 4.-Percentage of nests in snags

\begin{tabular}{|c|c|c|}
\hline Species & $\begin{array}{l}\text { Number of } \\
\text { nests }\end{array}$ & $\begin{array}{c}\text { Number } \\
\text { (and percent) of } \\
\text { nests in snags }\end{array}$ \\
\hline Violet-green swallow & 41 & $41(100)$ \\
\hline Pygmy nuthatch & 34 & $30(88)$ \\
\hline Western bluebird & 33 & $23(70)$ \\
\hline Mountain chickadee & 8 & $5 \quad(62)$ \\
\hline White-breasted nuthatch & 12 & 1 (8) \\
\hline Brown creeper & 4 & $4(100)$ \\
\hline House wren & 2 & $0 \quad(0)$ \\
\hline Western flycatcher & 1 & $0 \quad(0)$ \\
\hline Flammulated owl & 1 & $1(100)$ \\
\hline Totals & 144 & $105(73)$ \\
\hline
\end{tabular}




\section{Diameter of Selected Snags}

Species differences in the d.b.h. of snags used for nest sites were examined using analysis of variance. The birds did not possess significantly different preferences for size of snag to use for nests. Ranges of d.b.h. for the several species show a considerable degree of overlap (table 5). Birds showed a strong preference for snags in the 60- to 70-cm-diameter class. Seventy-five percent of the nests were located in snags with a diameter greater than $60 \mathrm{~cm}$.

$\begin{array}{cc}\text { Diameter class } & \text { Percent used } \\ \text { cm } & \\ & \\ 20-30 & 2 \\ 30-40 & 1 \\ 40-50 & 5 \\ 50-60 & 17 \\ 60-70 & 28 \\ 70-80 & 18 \\ 80-90 & 18 \\ 90-100 & 8 \\ 100-110 & 1 \\ 110-120 & 2\end{array}$

\section{Height of Snags Selected}

The birds selected snags with heights ranging from 2 to $36 \mathrm{~m}$. Approximately $63 \%$ of all the snags used as nest sites were $20 \mathrm{~m}$ and taller.

$\begin{array}{cr}\text { Height classes } & \text { Percent use } \\ \text { m } & \\ 0-4 & 2 \\ 4-8 & 12 \\ 8-12 & 3 \\ 12-16 & 14 \\ 16-20 & 6 \\ 20-24 & 28 \\ 24-28 & 26 \\ 28-32 & 6 \\ 32-36 & 3\end{array}$

\section{Bark Cover}

The frequency of all nests in different bark classes was tested using chi-square. This test shows that nests of SCN's are found more frequently $(\mathrm{P}<0.001)$ in snags covered by bark than in snags with varying degrees of bark present (table 6).

\section{Height of Cavity from the Ground}

The mean height of cavities used by the birds was similar to the mean height of unused cavities on each study plot (table 7). This indicates that SCN's selected cavity heights in proportion to their availability. On the G. A. Pearson Natural Area, however, there appeared to be a slight trend for the use of the higher cavities.

\section{Presence or Absence of Snag Tops}

A high percentage of the snags used by SCN's had broken tops. There were broken tops on $66 \%$ of all the snags used as nest sites, but only $32 \%$ of all available snags were without tops. No species differences were evident, although, in most cases, the pygmy nuthatch utilized a higher percentage of broken-topped snags for nest sites than did the other species.

\section{Presence of Bark Around the Cavity Entrance}

All species appeared to prefer cavities with bark directly around the nest entrance. On the G. A. Pearson Natural Area, 98\% of all the cavities used had bark encircling the entrance; on watersheds 8 and 14, the percentages were $82 \%$ and $100 \%$, respectively. The percentage of all the available cavities with bark directly around the entrance was $58 \%$.

\section{Characteristics of Nest Sites in Oaks}

Of the species which utilized oaks as alternative nesting sites, all selected nest sites in the largerdiameter trees $(25.4-72.2 \mathrm{~cm})$. There was a wide range in the height of cavities selected in oaks by SCN's (table 8).

Table 5.-Average d.b.h. of snags used by the birds of the ponderosa pine forest

\begin{tabular}{lcccr}
\hline Species & $\begin{array}{c}\text { Number of } \\
\text { nests }\end{array}$ & $\begin{array}{l}\text { Mean } \\
\text { d.b.h. }\end{array}$ & $\begin{array}{c}\text { Standard } \\
\text { deviation }\end{array}$ & $\begin{array}{c}\text { Range of } \\
\text { d.b.h. }\end{array}$ \\
\hline Violet-green swallow & & & & \\
Pygmy nuthatch & 41 & 75.1 & 15.0 & $52.1-114.6$ \\
Western bluebird & 30 & 67.8 & 14.0 & $41.6-96.3$ \\
Mountain chickadee & 23 & 67.6 & 19.3 & $29.5-114.6$ \\
White-breasted nuthatch & 5 & 63.9 & 25.9 & $23.6-95.0$ \\
Brown creeper & 1 & 72.6 & & \\
Flammulated owl & 4 & 87.0 & 16.5 & $69.6-102.9$ \\
$\quad$ Totals & 1 & 64.0 & & \\
\hline
\end{tabular}


Table 6. - The different amounts of bark present around 105 nest holes

\begin{tabular}{lccccc}
\hline \multicolumn{1}{c}{ Species } & \multicolumn{5}{c}{ Bark classes } \\
\cline { 2 - 6 } & $\mathbf{0 . 2 0 \%}$ & $\mathbf{2 1 . 4 0 \%}$ & $\mathbf{4 1 \cdot 6 0 \%}$ & $\mathbf{6 1 \cdot 8 0 \%}$ & $\mathbf{8 1 \cdot 1 0 0 \%}$ \\
\hline Violet-green swallow & 4 & 1 & 8 & 8 & 20 \\
Pygmy nuthatch & 4 & 1 & 6 & 1 & 18 \\
Western bluebird & 1 & 1 & 2 & 4 & 15 \\
Mountain chickadee & 0 & 0 & 0 & 1 & 4 \\
White-breasted nuthatch & 0 & 0 & 0 & 0 & 1 \\
Brown creeper & 0 & 0 & 2 & 0 & 2 \\
Flammulated owl & 0 & 0 & 0 & 0 & 1 \\
$\quad$ & & & & 18 & 61 \\
\hline \multicolumn{1}{c}{ Total } & 9 & 3 & 18 & & \\
\hline
\end{tabular}

Table 7.-Comparison of height $(\mathrm{m})$ of cavities used and unused on three ponderosa pine forests

\begin{tabular}{|c|c|c|c|c|c|c|}
\hline & \multicolumn{6}{|c|}{ Height } \\
\hline & \multicolumn{3}{|c|}{ Used } & \multicolumn{3}{|c|}{ Unused } \\
\hline & $\mathbf{N}$ & Mean & Range & $\mathbf{N}$ & Mean & Range \\
\hline \multicolumn{7}{|l|}{ G. A. Pearson } \\
\hline Natural Area & 72 & 18.2 & 2.4-29.3 & 189 & 15.7 & $4.2-27.4$ \\
\hline Watershed 8 & 28 & 9.1 & $0.9-20.7$ & 29 & 9.4 & $2.1-21.0$ \\
\hline Watershed 14 & 10 & 8.6 & $2.1-19.8$ & 4 & 7.0 & $3.3-8.8$ \\
\hline
\end{tabular}

Table 8.-Characteristics of all nest sites in oaks

\begin{tabular}{lccccc}
\hline \multicolumn{1}{c}{ Species } & $\begin{array}{c}\text { Number of } \\
\text { nests }\end{array}$ & $\begin{array}{c}\text { Mean } \\
\text { diameter }\end{array}$ & Range & $\begin{array}{c}\text { Mean } \\
\text { height of } \\
\text { cavity }\end{array}$ & Range \\
\hline & & & & & \\
Pygmy nuthatch & 3 & 46.0 & $36.1-65.8$ & 2.9 & $1.3-6.1$ \\
Western bluebird & 9 & 35.6 & $25.4-65.0$ & 3.7 & $1.2-7.9$ \\
Mountain chickadee & 2 & 26.9 & $26.4-27.4$ & 2.4 & $2.4-3.3$ \\
White-breasted nuthatch & 9 & 37.7 & $28.4-43.7$ & 2.6 & $1.5-6.4$ \\
House wren & 1 & 38.1 & & 4.6 & \\
Western flycatcher & 1 & 77.2 & & 7.6 & \\
American kestrel & 1 & 32.8 & & 3.6 & \\
Total/means & 26 & 38.4 & $25.4-77.2$ & 3.3 & $1.2-7.9$ \\
\hline
\end{tabular}

\section{Winter Roost Sites}

Ten pygmy nuthatch winter roost sites were found on the G. A. Pearson Natural Area during the winter of 1975-1976. These were compared to 19 pygmy nuthatch nest sites located in the same area. No differences were found except that the mean height of roost cavities was $8 \mathrm{~m}$ lower than the mean height of the nesting sites.
Diameter of snags $(\mathrm{cm})$

Total height of snags $(\mathrm{m})$

Percent bark cover

Distance to nearest tree $(\mathrm{m})$

Height of cavity (m)

Percent with top off

Percent with bark around hole

$$
\mathrm{n}=
$$

\section{Means}

Nest

72.3

23.8

74.6

20.3

18.9

68.4

100.0

19
Roost

74.7

22.1

89.7

15.8

10.9

70.0

100.0

10 


\section{Snag Survival}

The percentage of snags standing declined with time since tree death. After 10-15 years, approximately $30 \%$ of all snags had fallen. Slightly more than $50 \%$ of snags were standing after 20-25 years. Very few additional snags had fallen until 45-50 years had passed. At this point, $25 \%$ of the original snags were still standing.

\begin{tabular}{rcrrr}
$\begin{array}{c}\text { Age } \\
\text { classes }\end{array}$ & $\begin{array}{c}\text { Number } \\
\text { dead }\end{array}$ & $\begin{array}{c}\text { Number } \\
\text { cut }\end{array}$ & $\begin{array}{c}\text { Number } \\
\text { standing }\end{array}$ \\
years & & & \multicolumn{2}{c}{ percent } \\
& & & & \\
$0-5$ & 39 & 0 & 39 & $(100)$ \\
$6-15$ & 59 & 8 & 36 & $(71)$ \\
$16-20$ & 26 & 7 & 13 & $(68)$ \\
$21-25$ & 30 & 4 & 14 & $(54)$ \\
$26-30$ & 47 & 14 & 14 & $(42)$ \\
$31-35$ & 21 & 2 & 9 & $(47)$ \\
$36-40$ & 36 & 9 & 10 & $(37)$ \\
$41-45$ & 23 & 8 & 6 & $(40)$ \\
$46-50$ & 20 & 8 & 3 & $(25)$
\end{tabular}

The loss of snags is more rapid at first and slows with time. The gradual decrease in attrition may be a result of sheltered snags. The regression equation explains $95 \%$ of the variability in percentage of snags standing $(\mathrm{P}<0.005)$ (fig. 8).

\section{Snag Age Preference}

SCN's preferred to nest in trees that had recently died. A significant number of nests were found in snags which had been dead less than 20 years (fig. 9). Within this age range, the birds used snags that were dead from 5 to 20 years more heavily than those dead for less than 5 years. If selection was based solely on snag availability, the number of nests located in the three youngest age classes should have been less than we found. Furthermore, assuming that snags accumulate

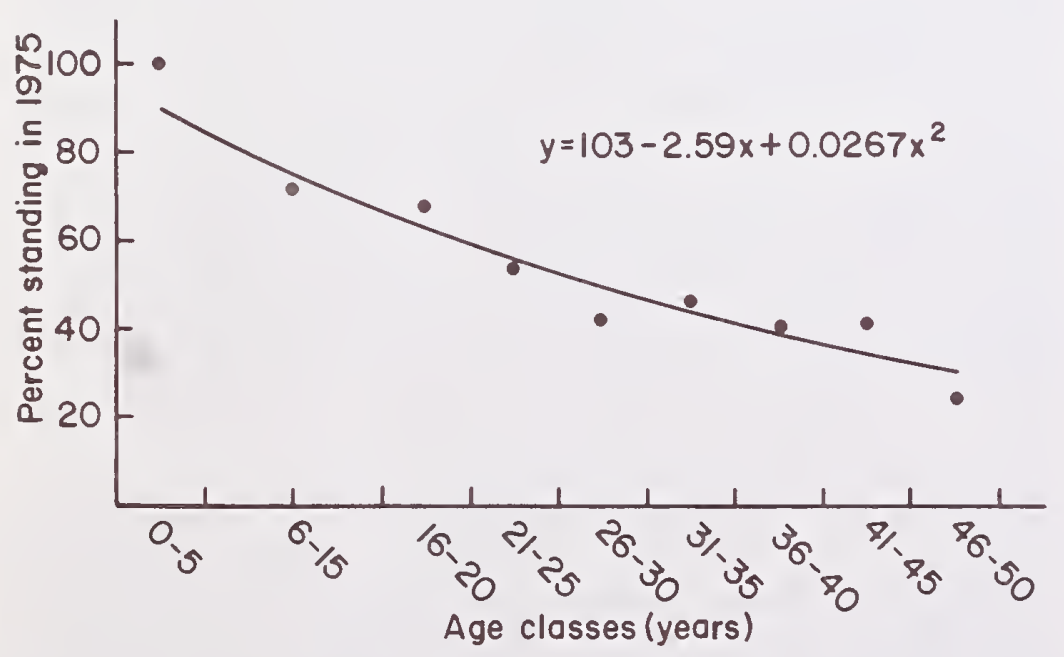

Figure 8.-Percentage of snags in nine age classes which were standing in 1975.



Figure 9.-Percentage of all nests within nine snag age classes.

cavities with time, a greater number of nests should be located in older snags if selection was based merely on availability.

\section{Discussion}

\section{Diversity and Number of SCN's}

Our findings are in essential agreement with other studies and support the idea that snag removal in a coniferous forest has a serious negative effect on the density of SCN's (fig. 9). Snag density alone explains more than half of the variability in density of SCN's (table 3). It is rather impressive that a single variable can explain such a high proportion of the variation. This is especially true considering that not all individuals nest in snags and that other environmental variables may also be important. For example, foliage volume of conifers probably represents a number of important niche dimensions such as quantity and quality of perches, food quantity (insects and seeds), territory size and quality, and shelter from weather and predators. These characteristics may be considered to allow survival in a coniferous forest, whereas, the snags allow reproduction there. This factor, although a significant one, contributed relatively little to the precision of the model once snags were accounted for.

Continuing research by the authors indicates that the year-to-year variability in breeding bird density of SCN's is low on areas of less than 60 snags per 40 ha and high at snag densities above 60. Other variables, perhaps winter and early spring low temperatures and snowfall amounts, are playing a different role at these higher snag densities.

The numbers of species of SCN's remained relatively constant between areas. Only when all snags had been removed (as in watershed 17) did a consistent reduction in the number of species occur. This was probably because of the loss of such snag-dependent species as violet-green swallow and brown creeper. Balda (1975) found seven species of SCN's breeding in areas where snags and oaks were present. He also found seven 
species in areas where snags were in low density and oaks were abundant. His findings are in agreement with this study.

In natural stands of ponderosa pine, it has been previously found that SCN's are $40-55 \%$ of the entire breeding bird population of the forest and $33 \%$ of the total breeding species (Balda 1975). The data collected from the G. A. Pearson Natural Area during this study support this conclusion. With reduced snag densities, however, the percentage of the total population contributed by the SCN's is reduced. In the G. A. Pearson Natural Area, the SCN's contributed more than onehalf of the total breeding-bird density. When snags were reduced, the SCN's contributed less to the total population. Although all bird species in the forest declined in density, SCN's declined more sharply due to the shortage of available cavities. The result was a decline in the percentage of the total breeding population made up by the SCN's. No correlation existed between the number or diversity of SCN species on an area and the density of snags present. This was probably due to the small size of the study plots. Over broad expanses of pine forest, it seems reasonable to predict a change in species diversity with a change in snag density. The bird species found on the study plots were differentially affected by snag removal. The violet-green swallow, pygmy nuthatch, mountain chickadee, and brown creeper nested predominantly in snags.

In this study, the mountain chickadee was less restricted to snags than Balda (1975) thought. The violet-green swallow, pygmy nuthatch, and brown creeper appeared specific in where they nest, and would be most affected by snag removal. In contrast, the density of white-breasted nuthatchs may, in part, be controlled by oak density, since this species nested predominantly in oaks during two breeding seasons. The western bluebird showed a drastic switch in the percentage of nest sites placed in snags as snag density declined. This species appeared to generalize in nest site selection more than the above species. In addition, Conner and Adkisson (1974) found that eastern bluebirds prefer areas where clearcutting had occurred. Stripcutting watershed 14 may have made the habitat more suitable for the western bluebird, resulting in an increase in its density. In order of decreasing sensitivity to snag removal, the species segregate into four groups. The most sensitive species are the violet-green swallow and brown creeper which use snags exclusively. The mountain chickadee and pygmy nuthatch will use oaks or live pines if snags are drastically reduced. The western bluebird is much less sensitive than the above species to low snag densities and utilizes oaks extensively at low snag densities. Finally, the white-breasted nuthatch shows no sensitivity to the density of snags and uses cavities in live pines or oaks almost exclusively for nest sites.

The ability of some species to switch from snags to other sites for nesting could explain why these species inhabit forest lands devoid of snags. Switching may also be the reason we did not achieve greater precision with our regression equation. In ponderosa pine forests, however, oak cavities and suitable holes in live trees are rare, and the removal of snags will result in a decline in SCN's.

\section{Characteristics of Nest Sites and Behavior of Birds}

In groups of species which use a common resource (such as snags and cavities), ecological isolation is particularly orderly and precise in its definition (Cody 1974). This ecological isolation is achieved by the subdivision of the total resource range into what is called species resource spans. This allows each species to use a small portion of the entire available resource.

All species used the largest diameter and tallest snags available on all the study plots. This would account for the variation in the size of snags used between study plots. On the watershed plots where smaller-diameter, shorter snags were available, the birds used snags that were different from those on the G. A. Pearson Natural Area. McClelland and Frissell (1975) found that birds selected the largest diameter and tallest snags of both western larch and paper birch. Moore (1945) suggested that this selection may be due to a slower loss of heat through thick layers of dry rotting wood in larger trees. His work was primarily concerned with winter-roost sites of birds, but the same heat demands are probably present during the spring and summer breeding season at high altitudes.

Birds selected those snags with the greatest amount of bark. Our findings place the lower limit of greatest bird use at $60 \%$ bark cover. SCN's selection of trees with high percentages of bark cover may actually reflect selection made initially by primary cavity nesters. Personal observation indicates that snags with little or no bark are primarily snags which are called "hard snags." These have a high pitch content and rot slowly. Those snags which retain their bark are usually "soft snags" which are more easily excavated by primary cavity nesters. It is possible, therefore, that the SCN's did not select for percent bark cover, but rather for those snags with suitable cavities, which conceivably would be more abundant in "soft snags."

In all species which nested in snags, a high percentage of cavities were selected which were surrounded by bark. The percentage ranged from $77.8 \%$ to $100 \%$ for all three study plots. Many cavities present on the study plots were not surrounded by bark, and only a few of these were occupied. Martin (1963) found in laboratory tests that bark and wood were nearly equal in their ability to absorb heat. In addition, he found that the insulative properties of bark were much higher than wood of the same density.

Brown creepers nearly always built their nest sites behind loose bark. As bark generally remains longer on the lower portion of snags, the brown creeper selected cavities at considerably lower heights than the other four species. The other species tended to nest in the highest cavities available. This might reflect a tend- 
ency on the part of the birds to nest as high as possible to reduce predation and/or intercept maximum solar radiation.

McClelland and Frissell (1975) found that $78 \%$ of all active nests in western larch were in snags with broken tops. Heartrot proceeds at a faster rate in snags with broken tops (Hepting 1971, Partridge and Miller 1974). The development of the heartrot is necessary in many situations to allow primary cavity nesters to excavate cavities.

In this study, $68 \%$ of all snags used for nest sites had broken tops. This selection of broken-topped snags may reflect a greater number of cavities in such snags because woodpeckers are prone to excavate in them. Thus, large numbers of usable cavities would accumulate in these snags. SCN's would then be more apt to select a cavity in a snag without a top than one in a snag with a top because of the differential number of available cavities.

Norris (1958) noted that nuthatches, on occasion, excavate cavities for their own use, thus behaving at times as primary cavity nesters. Pygmy nuthatches were found in snags with a higher percentage of broken tops than other species. This preference for snags with broken tops may be related to the higher degree of decay making it easier for nuthatches to excavate cavities.

McClelland and Frissell (1975) found numerous nest sites in dead tops of live trees, and over $80 \%$ of these were in those whose tops were broken. In this study, only three nest sites were found in the dead tops of live trees. This was probably because of the low density of live trees with dead tops which were decayed enough or with a diameter large enough for primary cavity nesters to have excavated a cavity in them. The dead tops of most of the live trees were devoid of bark, appeared to be extremely hard, and had small diameter.

\section{Characteristics of Nest Sites}

Nest sites in live pines were similar to those in snags. This suggests that some of the same criteria are being used by the birds whether they are selecting a nest site in a snag or live pine. The only obvious deviation from this pattern occurred in terms of the percentage of nests with bark around the entrance of the cavity since they were all located in lightning scars. Only in regions on these live trees where the bark was gone and insects and fungi had attacked the tree was the wood suitable for excavation.

As with snags selected as nest sites, oaks used by the birds tended to be large-diameter oaks. This may again be related to heat retention of large-diameter trees, but possibly more important in oaks is the physical limitation of small-diameter trees. Only in the large-diameter oaks could a cavity be located which would be large enough for a nest site.

\section{Characteristics of Winter-Roost Sites}

Five of the eight principle SCN's in the ponderosa pine forest overwinter there. These five species are insectivorous and comprised between $63 \%$ and $73 \%$ of all winter residents (Balda 1975).

Pygmy nuthatches selected the largest and tallest snags for nest sites and winter-roost sites. This may be because of the greater heat retention in larger snags. Heat acquired during the brief daylight hours is retained longer in large-diameter snags than in small ones (Мооге 1945). In addition, Moore also suggested that layers of dry rot frequently found in snags may further reduce heat loss by acting as insulation. Largediameter snags might be expected to contain greater amounts of dry rot than small-diameter snags.

The roost sites located during this study were approximately $8 \mathrm{~m}$ lower in height than the nest sites. A lower cavity height would reduce the effect of wind blowing into and агоund the cavity. Kendeigh (1960) stressed the importance to roosting birds of reducing wind to lower convectional heat loss.

Moore (1945) indicated that birds lose less heat if they fit closely in the cavity, thereby reducing heat loss from the bird's body into the cavity space. During the winter of 1975-76, several pygmy nuthatches frequently roosted in the same cavity. This has a two-fold effect-allowing a better fit within the cavity and increasing heat production for the entire group.

\section{Snag Survival}

The data indicate the rate snags fall is rapid at first and slows with time. The data differ from Keen's (1955) findings, possibly because of climatic differences. Keen's study was done in California where the rainfall is greater than in northern Arizona. The rate of rotting may be higher in the more mesic area, and dry soil may also act as a better anchor for the dead roots than wet soil.

\section{Snag Age Classes Used by Birds}

The greater number of nest sites was found in the youngest three classes (20 years and younger). These younger snags have a greater регcentage of bark cover present. Also, young snags are not as rotten as older ones, and the birds were observed to avoid nesting in snags which were extremely rotten.

\begin{tabular}{cl}
$\begin{array}{c}\text { Age of snag } \\
\text { years }\end{array}$ & \multicolumn{1}{c}{ Condition } \\
$0-5$ & $\begin{array}{l}\text { Needles still present } \\
\text { Small branches present } \\
\text { Bark all present }\end{array}$ \\
& $\begin{array}{l}\text { Small branches present } \\
\text { 90-99\% of bark present }\end{array}$ \\
& $\begin{array}{l}\text { Large branches present } \\
\text { 80-90\% of bark present }\end{array}$
\end{tabular}


Younger snags contain a larger number of insects (Baker 1973, Keen 1955). To build a nest in a snag which could also serve as a foraging location could be energetically advantageous to those species which glean insects from the bark.

Pygmy nuthatches, however, did not follow the above trend. They selected a higher percentage of older snags than did the other species. Norris (1958) noted that pygmy nuthatches, on occasion, excavated their own cavities, but that the bird's skull construction and musculature are not well developed for excavation. It would then be to their advantage to select for excavation those snags which are pulpy and rotten. This could explain the common occurrence of pygmy nuthatch nest sites in snags of older age.

\section{Additional Uses of Snags}

Snags were used extensively by birds other than for nest or roost sites. The following are the other uses and the species involved:

Hawking posts.-Western bluebird, pygmy nuthatch, and violet-green swallow.

Singing or drumming posts.-Western bluebird, common flicker, gray-headed junco, hairy woodpecker, and northern three-toed woodpecker.

Feeding substrates.-Pygmy nuthatch, whitebreasted nuthatch, brown creeper, hairy woodpecker, and northern three-toed woodpecker.

Perching and observation posts.-Violet-green swallow, western bluebird, and American kestrel.

The most frequently used snags were those which were tall and surrounded by few trees, thus providing the birds with a clear view of their surroundings. This was a particularly important characteristic for those species which used snags as territorial display posts and for predator detection. Those birds which used snags as a feeding substrate frequently selected snags which were recently dead (1-5 years) and had a high percentage of bark cover. Baker (1973) and Keen (1955) found that extensive populations of insect larvae invade recently dead trees. With time, the numbers of larvae drop off significantly. The peak in the number of insect larvae occurs about 2 years after the time of death of the trees. ${ }^{6}$ This would suggest that birds are seeking out snags which are recently dead.

\section{A Few Cautions}

1. This study concentrated only on SCN's. Other animals, particularly mammals and insects, make heavy use of snags and must be considered in future studies.

\footnotetext{
${ }^{6} J a c k m a n$, S. 1974. Some characteristics of cavity nesters: Can we ever leave enough snags? Paper presented to the Oregon Chapter of the Wildlife Society, January 1974.
}

2. Because of fire suppression practices, it is impossible to guess the number of snags standing in a pristine ponderosa pine forest. Most certainly there would be some, because wildfire creates as well as destroys snags.

3. This study views the avian community in the ponderosa pine forest as a stable one. The starling, an introduced SCN, is now invading the ponderosa pine forest, nesting in snags. If their populations continue to expand, they may become serious competitors with our native SCN's for suitable nesting sites.

4. Live trees designated as future snags in a snag recruitment program will provide two valuable resources needed by the SCN's-foliage volume for present use and suitable nest sites for the future.

\section{Literature Cited}

Allen, Robert W., and Margaret M. Nice. 1952. A study of the breeding biology of the purple martin (Progne subis). American Midland Naturalist 47:606-665.

Baker, W. Wilson. 1973. Longevity of lightning struck trees and notes on wildlife use. Proceedings of the Annual Tall Timbers Fire Ecology Conference 13:497-504.

Balda, Russell P. 1970. Effects of spring leaf-fall on composition and density of breeding birds in two southern Arizona woodlands. Condor 72:325-331.

Balda, Russell P. 1975. The relationship of secondary cavity nesters snag densities in western coniferous forests. USDA Forest Service Wildlife Habitat Technical Bulletin 1, 37 p. Southwestern Region, Albuquerque, N. Mex.

Burns, H. 1960. The economic importance of birds in forests. Bird Study 7:193-208.

Cody, Martin L. 1974. Competition and the structure of bird communities. 318 p. Princeton University Press, Princeton, N.J.

Conner, Richard N., and Curtis S. Adkisson. 1974. Eastern bluebirds nesting in clear cuts. Journal of Wildlife Management 38:934-935.

Dennis, John V. 1971. Species using red-cockaded woodpecker holes in northeastern South Carolina. Bird Banding 42:79-87.

Elliot, Charles N. 1945. Woodman, spare that "wolf" tree! American Forests 51:489-490.

Haapanen, A. 1965. Bird fauna of the Finnish forest in relation to forest succession. Annales Zoologici Fennici 2:153-196.

Haartman, Lars von. 1957. Adaptation in hole-nesting birds. Evolution 1:339-347.

Haartman, Lars von. 1971. Population dynamics. p. 391-399. In Avian biology. Donald S. Farner, and James R. King, editors. Academic Press, Inc., New York, N.Y.

Hepting, George H. 1971. Diseases of forest and shade trees of the U.S. U.S. Department of Agriculture, Agriculture Handbook 386, 658 p. U.S. Government Printing Office, Washington, D.C. 
Keen, F. P. 1929. How soon do yellow pine fall? Journal of Forestry 27:735-737.

Keen, F. P. 1955. The rate of natural falling of beetlekilled ponderosa pine snags. Journal of Forestry 53:720-723.

Kendeigh, S. Charles. 1944. Measurement of the bird populations. Ecological Monographs 14:67-106.

Kendeigh, S. Charles. 1960. Energy of birds conserved by roosting in cavities. Wilson Bulletin 73:140-147.

MacKenzie, J.M.D. 1952. The encouragement of birds in commercial plantations with nestboxes and other means. Scottish Forestry 6:10-17.

Martin, R. E. 1963. Thermal properties of bark. Forest Products Journal 13:419-426.

McClelland, B. Riley, and Sidney S. Frissell. 1975. Identifying forest snags useful for hole-nesting birds. Journal of Forestry 73(7):414-417.
Moore, A. D. 1945. Winter night habits of birds. Wilson Bulletin 57:253-260.

Norris, Robert A. 1958. Comparative biosystematics and life history of the nuthatches (Sitta pygmaea and S. pusilla). University of California Press Publications in Zoology 56(2):119-300.

Partridge, A. D., and D. L. Miller. 1974. Major wood decays in the inland northwest. 120 p. Forestry, Wildlife, and Range Experiment Station, Idaho Research Foundation, University of Idaho, Moscow.

Power, Harry W., III. 1966. Biology of the mountain bluebird in Montana. Condor 68:351-371.

Szaro, Robert C., and Russell P. Balda. 1979. Bird community dynamics in a ponderosa pine forest. Studies in Avian Biology 3:1-66.

Zeleny, Lawrence. 1972. Can we save the bluebird? Living Wilderness 36:24-31.
Alligator juniper

Gambel oak

Paper birch

Ponderosa pine

Western larch

\section{Appendix}

Flora List

Juniperus deppeana

Quercus gambelii

Betula papyrifera

Pinus ponderosa

Larix occidentalis

Fauna List

American kestrel

Brown creeper

Common flicker

Eastern bluebird

Flammulated owl

Gray-headed junco

Great tit

Hairy woodpecker

House wren

Mountain chickadee

Northern three-toed woodpecker

Pied flycatcher

Pygmy nuthatch

Violet-green swallow

Western bluebird

Western flycatcher

White-breasted nuthatch
Falco sparverius

Certhia familiaris

Colaptes auratus

Sialia sialis

Otus flammeolus

Junco caniceps

Parus major

Picoides villosus

Troglodytes aedon

Picoides tridactylus

Ficedula hypoleuca

Sitta pygmaea

Tachycineta thalassina

Sialia mexicana

Empidonax difficilis

Sitta carolinensis
Parus gambeli 


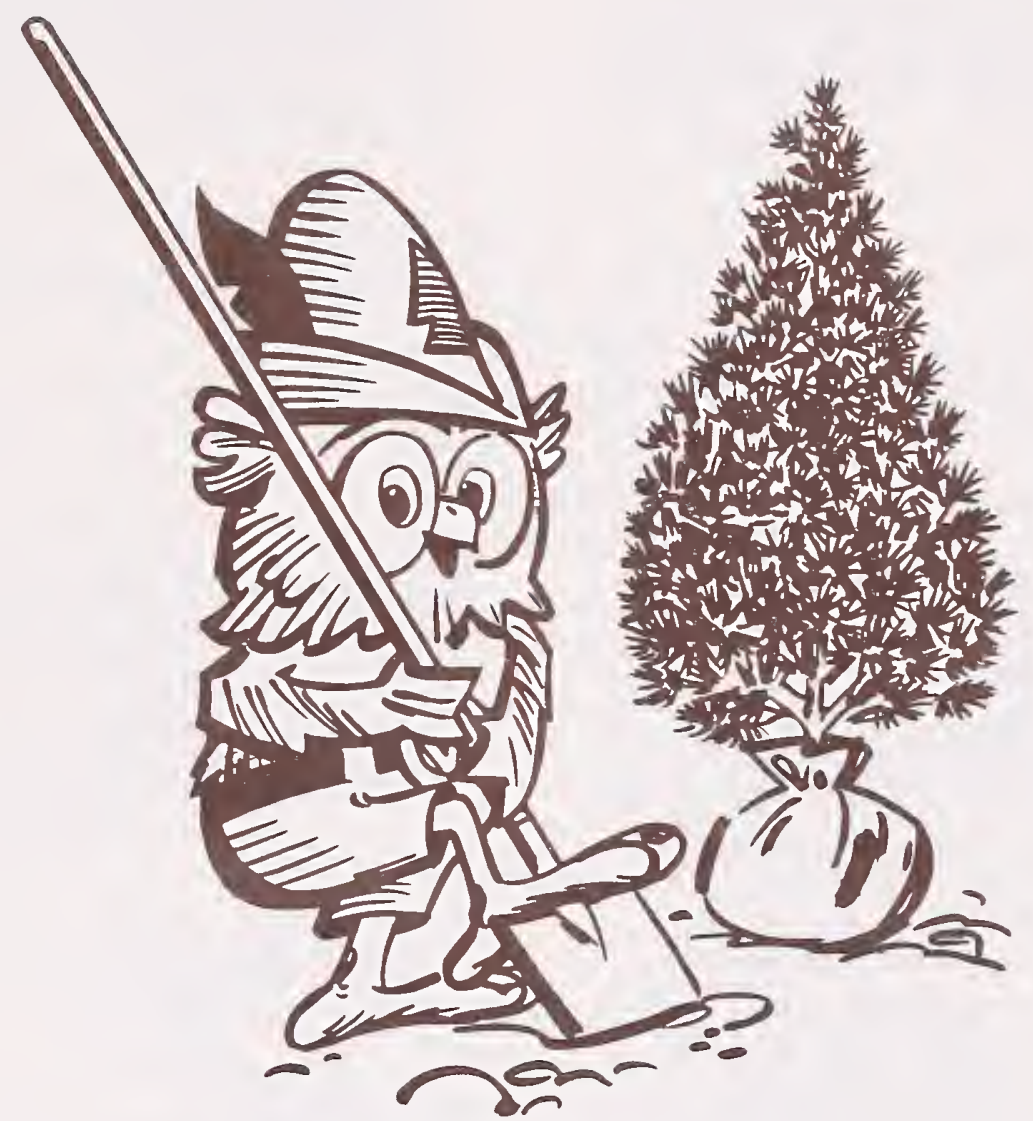

Plant a tree! Mark the 75th birthday of the Forest Service by giving a living gift to future generations. 




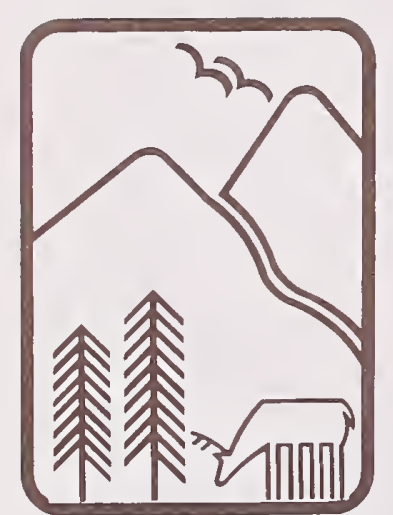

Rocky
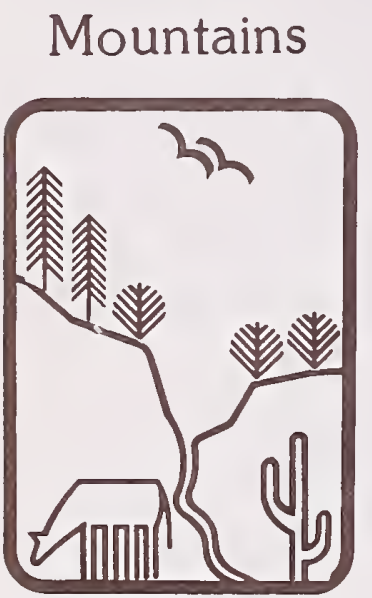

Southwest

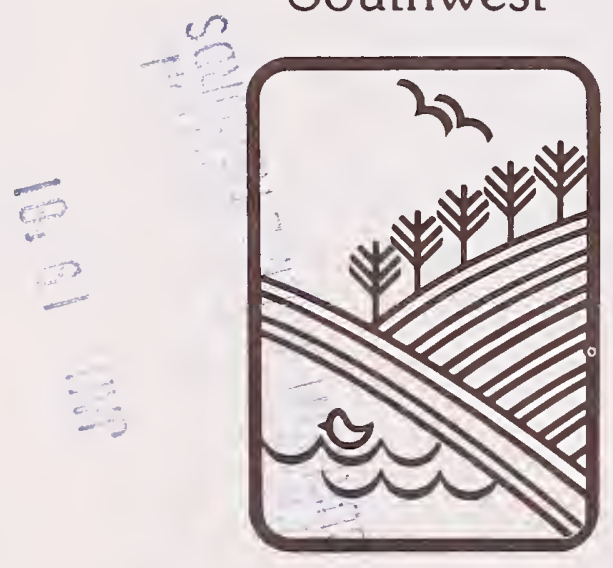

Great Plains
U.S. Department of Agriculture Forest Service

\section{Rocky Mountain Forest and Range Experiment Station}

The Rocky Mountain Station is one of eight regional experiment stations, plus the Forest Products Laboratory and the Washington Office Staff, that make up the Forest Service research organization.

\section{RESEARCH FOCUS}

Research programs at the Rocky Mountain Station are coordinated with area universities and with other institutions. Many studies are conducted on a cooperative basis to accelerate solutions to problems involving range, water, wildlife and fish habitat, human and community development, timber, recreation, protection, and multiresource evaluation.

\section{RESEARCH LOCATIONS}

Research Work Units of the Rocky Mountain Station are operated in cooperation with universities in the following cities:

Albuquerque, New Mexico

Bottineau, North Dakota

Flagstaff, Arizona

Fort Collins, Colorado*

Laramie, Wyoming

Lincoln, Nebraska

Lubbock, Texas

Rapid City, South Dakota

Tempe, Arizona

"Station Headquarters: 240 W. Prospect St., Fort Collins, CO 80526 